Institute of $\mathbf{F}_{\text {ood and }} \mathbf{A}$ gricultural $\mathbf{S}_{\text {ciences }}$

\title{
"Rag-Doll" Test for Seed Germination 1
}

\section{G. Chambliss (editor) ${ }^{2}$}

It is often important to determine the potential germination rate of seeds that have been held over from previous years. A fairly simple procedure can be conducted at home. Seeds that will not germinate in an ideal environment like that of a "rag doll" most likely will not germinate in the field.

Properly used, the rag-doll test is very valuable. The following are some suggestions to help you obtain the most reliable results.

- Use a firm paper towel such as a brown hand towel or equivalent. The soft, very absorbent paper towels often used in a kitchen make poor rag dolls because they allow roots and shoots to penetrate into the fiber, making seedlings difficult to remove during counting. If no other type of towel is available, the soft towels can be used, but it is best to use two layers. These towels often hold too much water, which drowns the seeds.

- Wet the towel and allow free water to drip off for a minute. Lay the wet towel flat and add seeds.
- Count out 100 seeds (50 for larger seeds like corn, peanuts, and soybeans) and place them on one half of the towel. Fold the towel over and roll it into a moderately tight tube. Rolling it around a pencil works well. Place the tube in a jar or sealable plastic bag.

- Position the rag doll so the tube is upright - doing this causes roots to grow down and shoots to grow up so that seedlings are more easily removed during counting. The rag doll should be kept in a warm place (between $75^{\circ}$ and $85^{\circ} \mathrm{F}$ ). A little water in the bottom of the jar or plastic bag ensures adequate moisture.

- Make the first germination count in about three days, for most crops. Open the towel and count the seedlings as you remove them. After another three to four days make another count. If you had 100 seeds, the number of seedlings removed equals the percentage germination.

- You can distinguish hard or firm (dormant) seeds from dead seeds by pushing down on each nongerminated seed with the flat part of a pencil eraser. If the seed does not flatten with gentle

1. This document is SS-AGR-179, one of a series of the Agronomy Department, Florida Cooperative Extension Service, Institute of Food and Agricultural Sciences, University of Florida. First published 1999. Revised August 2002. The information in this document was adapted from Production and Utilization of Pasture and Forages in North Carolina, Technical Bulletin 305, North Carolina Agricultural Research Service, North Carolina State University and is published with their permission. This publication is also part of the Florida Forage Handbook, an electronic publication of the Agronomy Department. For more information you may contact the editor of the Florida Forage Handbook, C. G. Chambliss (cgc@ifas.ufl.edu). Please visit the Edis website at http://edis.ifas.ufl.edu.

2. C. G. Chambliss (editor), associate professor, Agronomy Department; Florida Cooperative Extension Service, Institute of Food and Agricultural Sciences, University of Florida, Gainesville, 32611. The use of trade names in this publication is solely for the purpose of providing specific information. It is not a guarantee or warranty of the products named, and does not signify that they are approved to the exclusion of others of suitable composition.

The Institute of Food and Agricultural Sciences is an equal opportunity/affirmative action employer authorized to provide research, educational information and other services only to individuals and institutions that function without regard to race, color, sex, age, handicap, or national origin. For information on obtaining other extension publications, contact your county Cooperative Extension Service office. Florida Cooperative Extension Service/Institute of Food and Agricultural Sciences/University of Florida/Christine Taylor Waddill, Dean. 
pressure, it is considered hard. Dead seeds are usually moldy at the end of the test. 